\title{
Physiological and biochemical aspects of tomato seedlings treated with prohexadione-calcium
}

\author{
Fabrício Palla Teixeira ${ }^{1 *} \oplus$, Andrew Kim Lopes Ferraz ${ }^{1} \oplus$, Rafaelly Calsavara Martins ${ }^{1} \oplus$, \\ Tainá Mamede Cirne Silva²®, João Domingos Rodrigues ${ }^{3} \oplus$, Elizabeth Orika Ono ${ }^{3}[$ \\ 1 Universidade Estadual Paulista “Júlio de Mesquita Filho", Faculdade de Ciências Agornômicas, Departamento de Produção Vegetal, Botucatu, SP, Brasil. E-mail:
fabriciopallas@yahoo.com.br; andrewkim.lf@gmail.com; rcalsavara@yahoo.com.br
${ }^{2}$ Universidade Federal de Lavras, Departamento de Ciências Florestais, Lavras, MG, Brasil. E-mail: tainacirne@gmail.com
${ }^{3}$ Universidade Estadual Paulista “Júlio de Mesquita Filho”, Instituto de Biociências de Botucatu, Departamento de Botânica, Botucatu, SP, Brasil. E-mail: mingo@ibb.unesp.br;
elizabeth.o.ono@unesp.br
}

ABSTRACT: The objective of this experiment was to study the effects of different concentrations of the plant growth regulators prohexadione-calcium (ProCa) on the growth control of tomato seedlings. The experiment was conducted in the forest seedling nursery of the Faculty of Agronomic Sciences - UNESP, Botucatu Campus-SP. The experimental design was completely randomized, composed of five treatments: 0, 50, 100, 200 and $400 \mathrm{mg}$ of the active ingredient (a.i.) of ProCa, with 4 replicates of 30 seedlings. Treatments were applied with a manual $\mathrm{CO}_{2}$ sprayer when seedlings completed 20 days after sowing. Ten days after applying the treatments, seedling growth analysis, SPAD index, gas exchange, chlorophyll a fluorescence and biochemical analyses were all performed. From the results obtained, the conclusion was that ProCa concentrations inhibited seedling growth without compromising the photosynthetic apparatus.

Key words: antioxidant enzymes; fluorescence; growth; Solanum lycopersicum L.

\section{Aspectos fisiológicos e bioquímicos de mudas de tomateiro tratadas com proexadiona cálcica}

RESUMO: O objetivo do trabalho foi estudar os efeitos de diferentes concentrações do regulador vegetal proexadiona cálcica (ProCa) no controle do crescimento de mudas de tomateiro. O experimento foi conduzido no viveiro de mudas florestais da Faculdade de Ciências Agronômicas - UNESP, Campus de Botucatu-SP. 0 delineamento experimental foi 0 inteiramente casualizado, composto por cinco tratamentos: 0, 50,100, 200 e $400 \mathrm{mg}$ de ingrediente ativo (i.a.) de ProCa, com quatro repetições de 30 mudas cada. Os tratamentos foram aplicados com pulverizador manual de $\mathrm{CO}_{2}$ quando as mudas completaram 20 dias após a semeadura. Dez dias após a aplicação dos tratamentos foram realizadas análises de crescimento das mudas, índice SPAD, trocas gasosas, fluorescência da clorofila a e análises bioquímicas. Pelos resultados obtidos foi possível concluir que as concentrações de ProCa inibiram o crescimento das mudas, não comprometendo o funcionamento de seu aparato fotossintético.

Palavras-chave: enzimas antioxidantes; fluorescência; crescimento; Solanum lycopersicum L.

\footnotetext{
${ }^{*}$ Fabrício Palla Teixeira - E-mail: fabriciopallas@yahoo.com.br (Corresponding author)

Associate Editor: Giuseppina Pace Pereira Lima
} 


\section{Introduction}

Tomato plant (Solanum lycopersicum L.), part of the Solanaceae family, has its origins centered in the Andean region, covering Ecuador, Peru, Colombia, Bolivia and northern Chile. Although a perennial plant, it is cultivated worldwide as an annual instead (Peixoto et al., 2017). In Brazil, the tomato crop also plays an important role in feeding the population, with the states of Goiás, São Paulo and Minas Gerais, respectively, as its largest producers (IBGE, 2019). Production can be for the industry or for consumption in natura, with fruits classified according to their shape and caliber, which is the ratio between length and transversal diameter. For the market, fruits are split into five groups: Santa Cruz; Caqui; Salada; Saladete (Italian); and mini-tomatoes (Alvarenga, 2013).

In the market, the availability of hybrid tomato seeds is also a possibility. These are agronomically superior materials when compared to traditional cultivars. They also have a higher acquisition cost, due to greater productive potential, as well as resistance to bacterial, viral and nematode diseases. These materials are commonly grown under protected environment, whose producers have high technological level, thus reaching high yield rates (Alvarenga, 2013).

For plant species produced from seedlings, such as the tomato, this is one of the most important steps, since the final success of the project will depend on it in terms of yield, plant health and even the fruit nutritional value (Maggioni et al., 2014). A desirable seedling stand, besides having good rooting levels and a high survival rate after transplanting, should also demonstrate homogeneity in its shoot size. For tomato growers, in which seedling production occurs in high density, etiolation may be used in order to reduce costs, but compromising the viability of the production activity in turn (Seleguini et al., 2013).

In recent decades, using plant regulators as a strategy for plant production has been gaining prominence around the world. Plant regulators are synthetic substances that act in the regulation of metabolic and physiological processes, promoting or inhibiting plant growth, such as plant hormones (Espindula et al., 2010). Application can be held by different ways, including seeds and cuttings, leaves and via soil, as long as the characteristics of the product and the plant species are paid attention to (Seleguini et al., 2013; Melo et al., 2014; Pereira et al., 2016).

Plant regulators (phytohormones) act physiologically in several ways on plants such as growth regulation, stimulation of production and yield, improvement in fruit quality and harvest operations (Fagan et al., 2015). Plant regulators used in agronomic practices to control plant growth mostly act by inhibiting the biosynthesis of gibberellins. Depending on their group and action mode, these products may act in one of the three stages of gibberellin biosynthesis (Mouco et al., 2010).

Inhibitors of gibberellin biosynthesis are divided into three groups: the first one acts by blocking ent-caurene synthesis, preventing its formation from geranylgeranyl-diphosphate
(Espindula et al., 2010); the second group blocks GA12aldehyde, not enabling the oxidation of ent-caurene by the ent-caurene oxidase enzyme (Rademacher, 2000); and the third group acts in the last step of gibberellin biosynthesis, in competition for the binding sites of the dioxygenases. Acylcyclohexadiones such as Prohexadione-calcium represent this last group (Espindula et al., 2010).

Prohexadione-calcium (ProCa: calcium 3-oxide-4propionyl-5-oxo-3-cyclohexane carboxylate) is a plant growth regulator already employed for some years to control growth in some cereal and fruit species and, in more recent researches, on vegetable species (Altintas, 2011; Ozbay \& Ergun, 2015). Today, ProCa is classified as a low-toxicological compound with no mutagenic, carcinogenic or teratogenic effects as well as having no harm to bees, fish, birds, mammals and the soil microbiota. Thereby, ProCa may be a viable alternative for agronomic use, considerably reducing damage to plants and the environment (Evans et al., 1999).

Many are the gaps that need to be filled about using plant regulators in seedlings. Studies are restricted within the literature on this subject, with rare exceptions that only evaluate seedling growth variables, not investigating more deeply the possible responses of seedlings in other aspects such as their physiology and biochemistry. Analyses of gas exchange and chlorophyll $a$ fluorescence can indicate the effects of ProCa application on photosynthesis, especially in the potential quantum efficiency of photosystem II (Fv/ $\mathrm{Fm}$ ), as this is a sensitive indicator of the photosynthetic performance of plants (Krause \& Weis, 1991). Quantifying lipid and enzyme peroxidation may point out possible levels of oxidative stress caused by ProCa, thus indicating possible damage to cell membranes and the action of antioxidant enzymes, such as superoxide dismutase (SOD), catalase (CAT) and peroxidase (POD), producing a more complete picture of the plant regulator action in plants. These answers may help nurserymen and growers, contributing to the advancement of tomato cropping, making the sector more efficient and competitive.

In light of the foregoing, the objective of this study was to evaluate the effects of different ProCa concentrations on the growth control of tomato seedlings.

\section{Materials and Methods}

The experiment was conducted in a greenhouse on the premises of the Faculty of Agronomic Sciences - UNESP, Botucatu campus-SP (latitude: 22 $51^{\prime} 22.1^{\prime \prime} \mathrm{S}$, longitude: $\left.48^{\circ} 26^{\prime} 01.0^{\prime \prime} \mathrm{W}\right)$. Seedlings were prepared from seeds of the hybrid 'Santy', from Sakata Seeds Sudamerica, in 128-cell trays with commercial substrate (Carolina Soil II'). After sowing, trays were kept in the greenhouse, under sprinkling, with irrigation frequency of 30 seconds every hour. At twenty days after sowing (DAS), with the seedlings already with one pair of expanded leaves, the treatments were applied.

Treatments were composed of concentrations containing 0, 50, 100, 200 and $400 \mathrm{mg}$ of Prohexadione-calcium (ProCa) 
(Viviful ${ }^{\circ}$ with $27.5 \%$ a.i.), from Iharabras S.A company. The experimental design was the entirely randomized, with four replicates of 30 seedlings each. Plant regulator was mixed with water directly in the application container together with an adjuvant agent. Treatments were applied by leaf spraying with a pressurized $\mathrm{CO}_{2}$ manual sprayer, with $0.3 \mathrm{kgf} \mathrm{cm}^{-2}$, conical nozzle, of the model $\mathrm{X} 2$, having an estimated flow rate of $3.5 \mathrm{~mL}$ per cell.

Ten days after applying the treatments, when seedlings completed 30 days after sowing (DAS), also considering the time required for them to be ready for transplanting in this period, the following evaluations were performed in ten seedlings per replicate: number of leaves; stem length, by measuring from the stem base to the petiole of the first pair of leaves with digital pachymeter; leaf length, by measuring from the sheath to the end of the terminal leaflet; leaf width, in the median leaf region; Spad index (total chlorophyll concentration) in terminal leaflets, using a portable chlorophyllometer (Model 502 - Minolta), obtaining values from the mean of five readings per fully expanded leaf of each seedling.

The physiological parameters of gas exchange and chlorophyll $a$ fluorescence were evaluated by using an equipment of open-photosynthesis system with $\mathrm{CO}_{2}$ and water vapor analyzer by infra-red radiation (Infra-Red Gas Analyser - IRGA, model LI-6400, - LI-COR), with a coupled fluorometer. For gas exchange parameters, the following were analyzed: $\mathrm{CO}_{2}$ assimilation rate $\left(A, \mu \mathrm{mol} \mathrm{CO}_{2} \mathrm{~m}^{-2} \mathrm{~s}^{-1}\right)$; transpiration rate $\left(E, \mathrm{mmol}\right.$ water vapor $\left.\mathrm{m}^{-2} \mathrm{~s}^{-1}\right)$; stomatal conductance ( $g s$, $\left.\mathrm{mol} \mathrm{m} \mathrm{m}^{-2} \mathrm{~s}^{-1}\right)$ and internal $\mathrm{CO}_{2}$ leaf concentration $(\mathrm{Ci}, \mu \mathrm{mol}$ $\mathrm{CO}_{2} \mathrm{~mol}^{-1}$ ). For physiological fluorescence parameters, the saturated pulse method was used with the nomenclature recommended by Baker \& Rosenqvist (2004), obtaining the following parameters: potential quantum efficiency of FSII (FV) $F m)$; antenna quantum efficiency $\left(F v^{\prime} / F m^{\prime}\right)$; photochemical extinction coefficient $(q P)$; non-photochemical extinction coefficient $(q N P)$ and electron transport apparent rate (ETR). For both parameters, one seedling per replicate was used and the measurements took place between 07:00 and 11:00 am.

Seedlings were also biochemically evaluated by lipid peroxidation (TBAR), determined by the technique described by Heath \& Packer (1968); determination of enzyme activity: superoxide dismutase (SOD), by the method of Giannopolitis \& Reis (1977); catalase (CAT), by the methodology described by Peixoto et al. (1999); and peroxidase (POD), determined according to Teisseire \& Guy (2000). For the analyses, leaves from ten seedlings per replicate were used, which had been instantly frozen in liquid nitrogen and then stored in an ultrafreezer at $-85^{\circ} \mathrm{C}$ until the analyses.

Data were submitted to the Shapiro-Wilk SPSS normality test, without the need of undergoing transformations. Means of the variables were submitted to variance analysis and grouped by using the Scott-Knott test, with those that were significant at $5 \%$ level also submitted to the regression analysis later. The statistical analyses were performed using the open access software $\mathrm{R}$ version 3.3.2.

\section{Results and Discussion}

Treatments for the variables stem length, leaf number, leaf length and leaf width were significant, showing a linear reduction by the ProCa concentrations (Figure 1). For all ProCa treatments, stem length was reduced by $18,41,49$ and $57 \%$, respectively, at increasing concentrations of the plant regulator containing 50, 100, 200 and $400 \mathrm{mg}$ active ingredient (a.i.) when compared to the control (Figure 1A). For leaf number, only the $400 \mathrm{mg}$ concentration differed from the control and the other treatments (Figure 1B). For leaf length, all treatments differed from the control, having reductions of $15,39,35$ and $36 \%$, respectively, with the increasing ProCa concentrations, with no significant difference among treatments (Figure $1 \mathrm{C}$ ). Similar response was also observed for leaf width, where ProCa concentrations reduced leaf width when compared to the control group (Figura 1D).

Pereira et al. (2016) observed polynomial and linear behavior for the reducted vegetative growth in Fragaria $\mathrm{x}$ ananassa D. regarding the studied variables in presence of ProCa at concentrations between 50 and $800 \mathrm{mg} \mathrm{L}^{-1}$. Efficiency of ProCa in reducing vegetative growth was also found in other studies with tomato (Giannakoula \& Ilias, 2007; Altintas, 2011) and in other plant species such as Malus domestica B. (Guak, 2013), Solanum melongena L. (Ozbay \& Ergun, 2015) and Fragaria $\mathrm{x}$ ananassa D. (Kim et al., 2019). Increasing ProCa concentrations applied to seedlings inhibited gibberellin biosynthesis, possibly by competing with the binding sites of dioxygenases (Espindula et al., 2010). Reductions in the
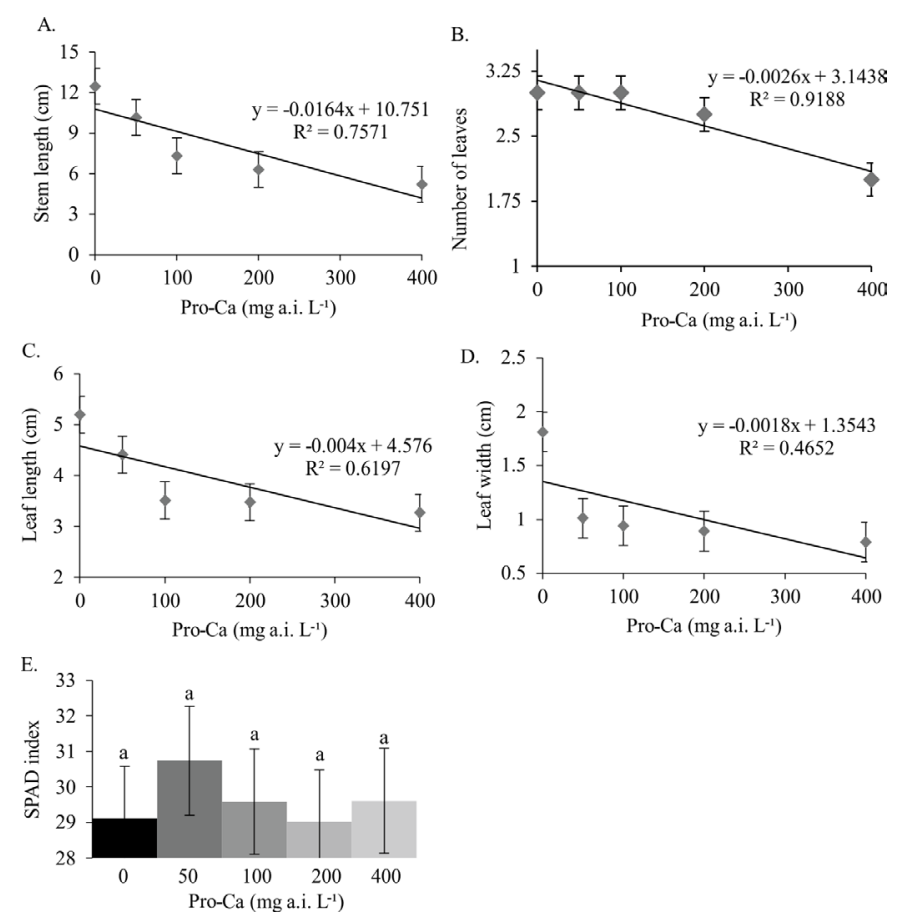

Figure 1. Stem length in $\mathrm{cm}(A)$; number of leaves (B); leaf length in $\mathrm{cm}(C)$; leaf width in $\mathrm{cm}$ (D); and SPAD index (E) in 'Santy' tomato seedlings, subjected to different of Prohexadione-calcium (ProCa) concentrations, 10 days after applying the treatments. 
vegetative growth in tomato seedlings, when in the presence of ProCa, especially at the higher concentrations (200 and 400 $\mathrm{mg} \mathrm{L}^{-1}$ ), possibly occurred due to hormonal regulation due to the presence of plant regulator in the metabolism of the seedlings. This promoted a possible reduction in the levels of endogenous gibberellins, possibly $\mathrm{GA}_{1}$ and $\mathrm{GA}_{4}$, as they are the main gibberellins active in plant growth (Pereira et al., 2016) and inhibiting cell elongation, which in this study is evidenced by the stem length of seedlings treated with ProCa (Figure 2).

ProCa concentrations had no significant effect on the SPAD index in tomato seedlings (Figure 1E). Different authors found different responses of the SPAD index, which is an indirect way to quantify the chlorophyll content in vegetables. Kofidis et al. (2008) also observed no significant difference in chlorophyll contents when studying Coriandrum sativum in presence of ProCa at concentrations of 100 and $200 \mathrm{mg} \mathrm{L}^{-1}$ applied at three different times. However, Giannakoula \& Ilias (2007), working with Solanum lycopersicum L., concluded ProCa promoted significant decline in the chlorophyll content within the analyzed leaves at doses of 100,200 and $300 \mathrm{mg} \mathrm{L}^{-1}$, sprayed at two distinct times at 10-day intervals. The same authors argue that the reduction may have been caused by photoxidation. Already in Solanum melongena L. seedlings, Ozbay \& Ergun (2015) observed an increase in chlorophyll content after a single application of ProCa at concentrations of 100 and 150 $\mathrm{mg} \mathrm{L}^{-1}$.These same authors hypothesized that seedlings under
ProCa effect had lesser leaf area and, as a compensatory strategy, synthesized more chlorophyll molecules.

These different results demonstrate that it is still unclear how ProCa acts on chlorophyll metabolism. In short, chlorophylls are pigments specialized in absorbing light and transferring radiant energy to the reaction centers, allowing the functioning of the photosynthetic apparatus (Taiz et al., 2017). In the present study, as the chlorophyll values were not significantly influenced by the treatments, even if not investigated, it can ultimately be stated that ProCa did not affect the biosynthesis of pigments involved in photosynthesis significantly (Taiz et al., 2017).

When evaluating the physiological parameters of gas exchange and chlorophyll $a$ fluorescence, there was also no significant effect of the treatments compared to the control (Table 1). Giannakoula \& Ilias (2007) found similar results, studying two cultivars of Solanum lycopersicum L., where after applying 100, 200 and $300 \mathrm{mg} \mathrm{L}^{-1}$ of ProCa; they observed no change in the internal carbon $\mathrm{Ci}$ concentration for the Karla cultivar, as well as, the transpiration rate $E$ for the Hari Moran cultivar also did not differ significantly. Medjdoub et al. (2007), working with Malus domestica B. of the Royal Gala variety, also found no significant difference in $\mathrm{CO}_{2}$ assimilation rates $A$, in $E$ and in stomatal conductance $g s$ in tomato leaves in presence of ProCa at concentrations of 125 and $250 \mathrm{mg} \mathrm{L}^{-1}$. Thomidis et al. (2018) found the same result in the Xinomavro cultivar of

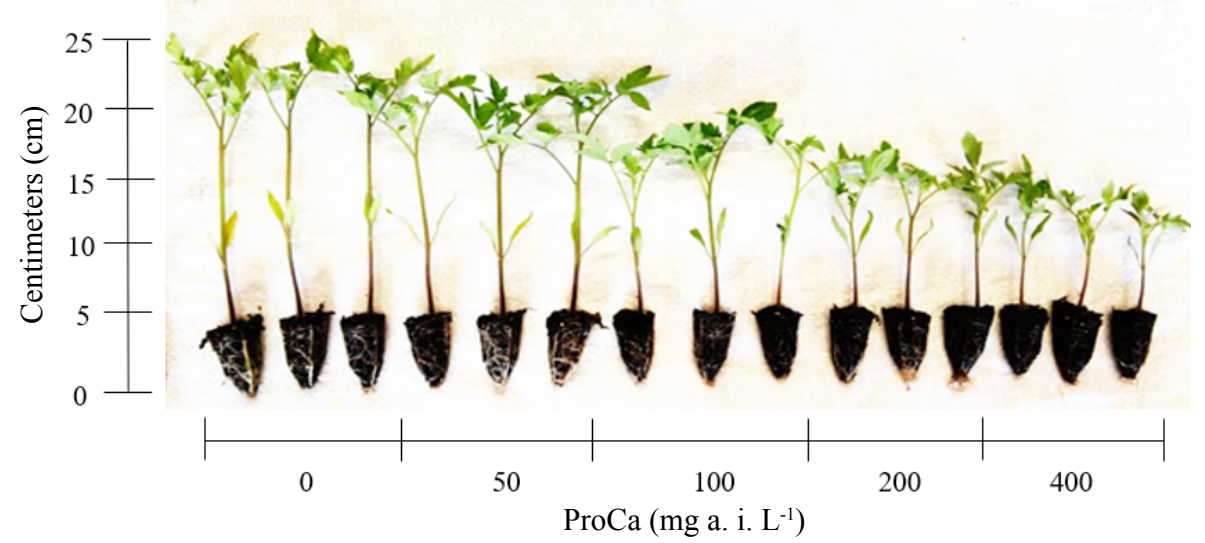

Figure 2. Height of 'Santy' tomato seedlings $(\mathrm{cm})$ subjected to different Prohexadione-calcium (ProCa) concentrations, in mg $\mathrm{L}^{-1}$, at 10 days after applying the treatments.

Table 1. Mean values of the assimilation rate of $\mathrm{CO}_{2}\left(A, \mu \mathrm{mol} \mathrm{m} \mathrm{m}^{-2} \mathrm{~s}^{-1}\right)$; stomatal conductance $\left(g s, \mathrm{~mol}^{-2} \mathrm{~s}^{-1}\right)$; internal concentration of $\mathrm{CO}_{2}$ in the leaf $\left(C i, \mu \mathrm{mol} \mathrm{mol}{ }^{-1}\right)$; transpiration rate $\left(E, \mathrm{mmol} \mathrm{m}^{-2} \mathrm{~s}^{-1}\right)$; water usage efficiency $\left(E U A, \mu \mathrm{mol} \mathrm{CO}_{2}\left(\mathrm{mmol}_{2} \mathrm{O}\right)^{-1}\right)$; carboxylation efficiency $(A / C i)$; potential quantic efficiency of FSII $(F v / F m)$; quantic efficiency of antennas $\left(F v^{\prime} / F m^{\prime}\right)$; photochemical extinction coefficient $(q P)$; non-photochemical extinction coefficient (NPQ) and electron transport apparent rate (ETR), in 'Santy' tomato seedlings subjected to different Prohexadione-calcium (ProCa) concentrations.

\begin{tabular}{cccccccccccc}
\hline $\begin{array}{c}\text { ProCa } \\
\text { (mg a.i. L-1) }\end{array}$ & $\boldsymbol{A}$ & gs & $\boldsymbol{C i}$ & $\boldsymbol{E}$ & EUA & A/Ci & Fv/Fm & Fv'/Fm' & qP & NPQ & ETR \\
\hline T1- 0 & 23.81 & 0.51 & 290.49 & 6.89 & 3.88 & 0.09 & 0.94 & 0.47 & 0.53 & 2.06 & 164.97 \\
T2- 50 & 24.31 & 0.54 & 292.57 & 7.07 & 3.86 & 0.09 & 0.93 & 0.47 & 0.51 & 1.98 & 167.58 \\
T3- 100 & 23.47 & 0.52 & 290.20 & 6.87 & 3.85 & 0.09 & 0.96 & 0.48 & 0.50 & 1.94 & 162.72 \\
T4- 200 & 23.47 & 0.52 & 291.25 & 6.73 & 3.81 & 0.09 & 0.95 & 0.47 & 0.51 & 1.99 & 165.47 \\
T5- 400 & 24.56 & 0.51 & 290.82 & 7.01 & 3.84 & 0.09 & 0.96 & 0.48 & 0.53 & 1.92 & 166.37 \\
CV (\%) & 1.58 & 2.65 & 0.44 & 1.58 & 0.48 & 1.16 & 1.22 & 1.51 & 2.11 & 2.94 & 1.48 \\
\hline
\end{tabular}


Vitis vinifera L., where ProCa application did not alter gs within the grapevine leaves. The process of chlorophyll excitation by light induces the formation of ATP and $\mathrm{NADPH}+\mathrm{H}^{+}$, and these products, in turn, are consumed in the Calvin-Benson cycle, by reactions catalyzed by enzymes that reduce atmospheric $\mathrm{CO}_{2}$ into phosphate trioses (Taiz et al., 2017). Given the foregoing, ProCa concentrations did not affect light and carboxylation reactions of photosynthesis, allowing the seedlings to develop normally.

Giannakoula \& Ilias (2007) obtained data contrasting to those presented here in this study, finding significant difference for $E$ and $C i$, with a reduction and lack of growth trend and decrease observed, respectively, in Solanum lycopersicum L. cultivars in presence of ProCa compared to the control. These same authors also found a reduction in $\mathrm{Fv} / \mathrm{Fm}$ in both studied materials.

ProCa can also potentiate the photosynthetic apparatus, as verified in Malus domestica B. of the Royal Gala variety that, in presence of ProCa, demonstrated increased $A$ when compared to the control with the increasing ProCa concentrations (Medjdoub et al., 2007). In Vitis vinifera L., ProCa presence at the concentration of $250 \mathrm{mg} \mathrm{L}^{-1}$ increased $A$ and $g s$ values by 12 and $22 \%$, respectively, compared to plants that did not receive the plant regulator (Thomidis et al., 2018). In adult plants of Fragaria x ananassa D., Kim et al. (2019) observed that after ProCa application, $\mathrm{Fv} / \mathrm{Fm}$ was increased in all treatments when compared to the control.

For Privé et al. (2006) ProCa effects on different plant species is conditioned to seasonality, the shoot growth pattern, the studied species, the employed management and biotic factors. In the present study, the plant material used
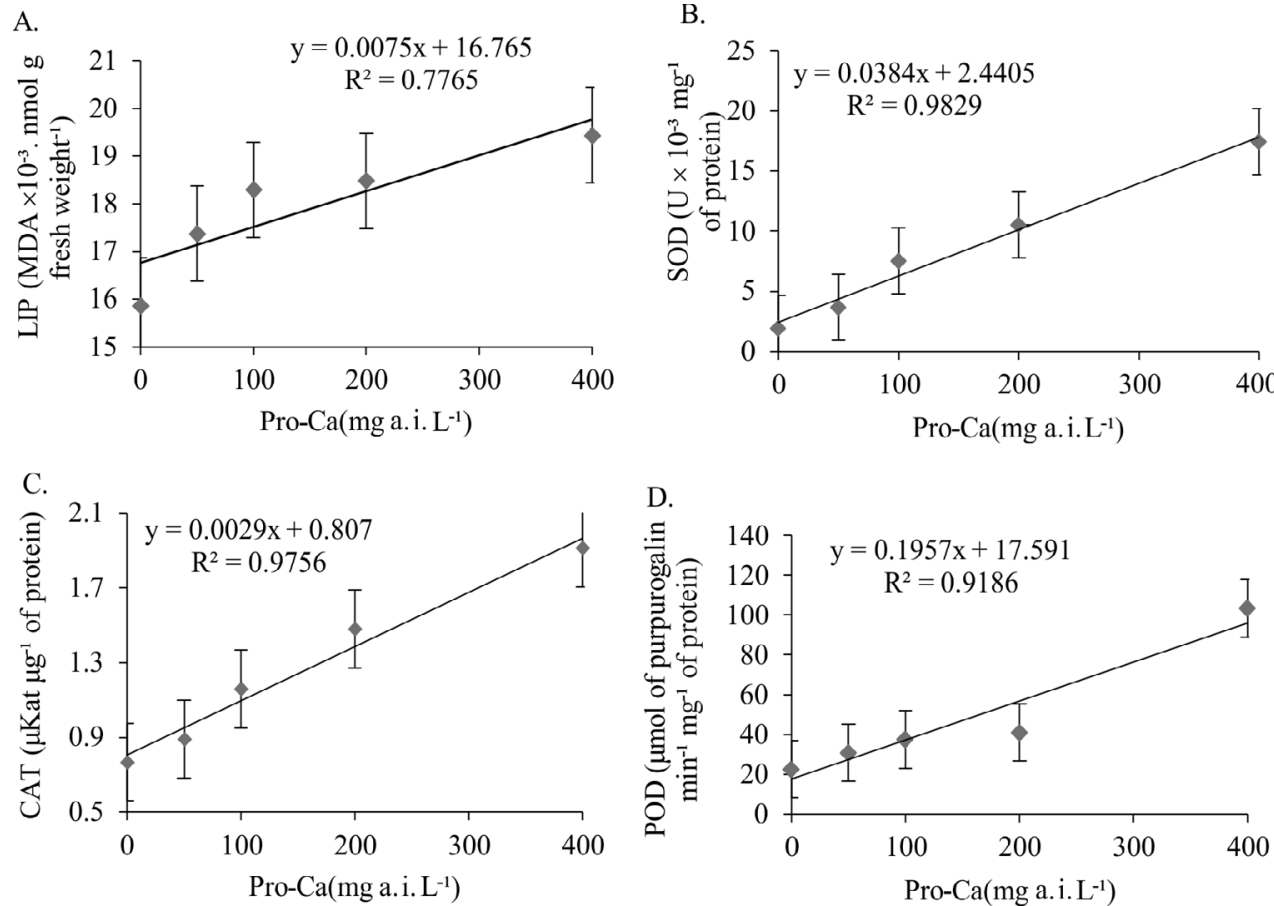

was a hybrid cultivated in a protected environment, restricting the action of environmental factors, associated with the correct management, both nutritional and phytosanitary may have contributed in the maintenance of the photosynthetic processes, even in presence of ProCa.

Non-significant variation found between treatments and the control, for the physiological fluorescence parameters, especially $\mathrm{Fv} / \mathrm{Fm}$, reinforces the approach that ProCa did not physiological impaired the seedlings. Potential quantum efficiency of FSII is a sensitive indicator of the plant photosynthetic performance (Krause \& Weis, 1991). However, in presence of stress, Bolhar-Nordenkampf et al. (1989) stated that $\mathrm{Fv} / \mathrm{Fm}$ values between 0.75 and 0.85 pointed to the overcoming of said stress, preventing photoinhibitory damage. Since values observed in tomato seedlings for Fv/ $\mathrm{Fm}$ were between 0.93 and 0.96 , it is possible to verify that these seedlings overcame a possible stress caused by ProCa, leading to activation of the antioxidant system, so as not to compromise the seedling physiological performance. This system may also have contributed to maintaining the integrity of chloroplast membranes, site responsible for the light reactions of photosynthesis (Taiz et al., 2017).

When investigating the influence of ProCa concentrations on biochemical aspects, significant difference between the treatments compared to the control were found (Figure 3). It was possible to observe moderate stress caused by ProCa concentrations, evidenced by lipid peroxidation values, which responded increasingly and linearly to the ProCa concentrations (Figure $3 \mathrm{~A}$ ). Although significant, the variation range of values between treatments was small, which may suggest that the plant regulator does not induce severe stress. In ProCa-

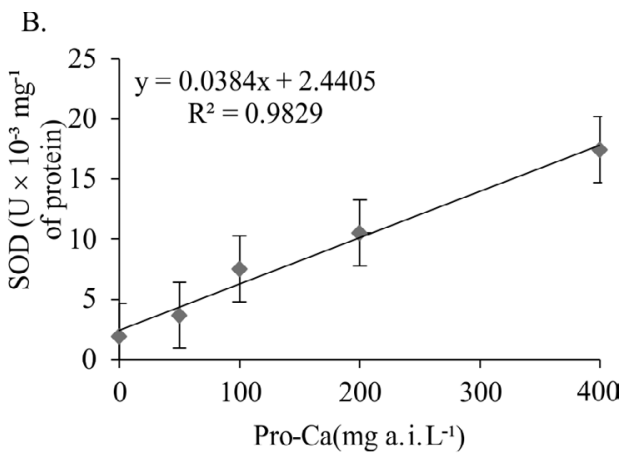

Figure 3. Lipid peroxidation (MDA $\times 10^{-3}, \mathrm{nmol}$ g fresh weight ${ }^{-1}$ ) (A); activities of the superoxide dismutase enzymes (SOD $\times 10^{-3}$, $\mathrm{U} \mathrm{mg} \mathrm{mo}^{-1}$ of protein) (B); catalase (CAT, $\mu$ Kat $\mu \mathrm{g}^{-1}$ of protein) (C) and peroxidase (POD, $\mu \mathrm{mol}$ of purpurogalin $\mathrm{min}^{-1} \mathrm{mg}^{-1}$ of protein) (D) in 'Santy' tomato seedlings subjected to different Prohexadione-calcium (ProCa) concentrations. 
treated grass, Rezapour Fard et al. (2015) also observed increased lipid peroxidation, finding malondialdehyde (MDA) accumulation and ion leakage. Lipid peroxidation, quantified by MDA content, is an important indicator for estimating cell membrane stability (Rachmilevitch, 2006).

Enzymatic activity presented a linear growth for the enzymes superoxide dismutase (SOD), catalase (CAT) and peroxidase (POD) concerning the ProCa concentrations (Figures 3B, 3C and 3D). An intense antioxidant activity was verified in the seedlings, which was indirectly measured by enzyme activities. In regards to the SOD enzyme, there was an increase of $89,289,444$ and $800 \%$ in the concentrations of 50, 100, 200 and $400 \mathrm{mg}$ a.i. $\mathrm{L}^{-1}$ of ProCa (Figure 3B). This very activity pattern was also observed for the CAT enzymes, having an increase in their activity when compared to the control of $17,52,94$ and $151 \%$, respectively, at increasing ProCa concentrations, and for POD with an increase of 36, 66, 82 and $360 \%$ also compared to the control (Figures $3 \mathrm{C}$ and 3D).

Pan et al. (2016) also observed the antioxidant action in Nicotiana tabacum L. seedlings that had the activity of SOD, CAT and POD enzymes increased in presence of increasing ProCa concentrations. In Rubus idaeus L. leaves, Dragišić Maksimović et al. (2017) found increased activity of SOD, CAT and POD enzymes in presence of ProCa in comparison to the control group by 117,12 and $31 \%$, respectively.

SOD is the primary enzyme active in combating reactive oxygen species (ROS), promoting the dismutation of the highly toxic superoxide radical into hydrogen peroxide and oxygen (Gill \& Tuteja, 2010). From the enzyme activity rates, we inferred that the seedlings suffered moderate stress due to ProCa concentrations. After SOD action, the enzymes CAT and POD act on $\mathrm{H}_{2} \mathrm{O}_{2}$, which undergoes dismutation and oxireduction, releasing in turn oxygen, water and the reducing agent. $\mathrm{H}_{2} \mathrm{O}_{2}$, which albeit not as damaging as the other ROS, can transpose membranes when at high concentrations, forming hydroxyl, the most reactive free radical (Gill \& Tuteja, 2010). However, this stress was not enough in compromising physiologically the seedlings. For Taiz et al. (2017), in concentrations that are not harmful to cells, ROS can have the functions of signaling and physiological regulation.

For any aerobic organism, the balance between ROS production and action of the antioxidant system is paramount for the functioning of its metabolism (Taiz et al., 2017). ROS in plants are eliminated by a variety of water-soluble molecules and antioxidant enzymes (Rezapour Fard et al., 2015), with the later as the most effective against oxidative damage of these (Foyer \& Fletcher, 2001). Results of this study allowed us to state that the balance between ROS and the antioxidant system in tomato seedlings treated with ProCa was kept, ensuring the maintenance of cellular structures, which in turn reflected on seedling vigor at the end of the experiment.

However, future studies are needed in order to investigate, after transplanting, the phenology of plants from seedlings that received ProCa application and its possible effects on fruit production and quality.

\section{Conclusions}

ProCa treatments inhibited the growth of tomato seedlings on all evaluated concentrations.

Chlorophyll content, physiological parameters of gas exchange and chlorophyll $a$ fluorescence were not affected by ProCa applications.

ProCa concentrations caused moderate stress to tomato seedlings, albeit not compromising their physiological development.

\section{Acknowledgements}

The authors would like to express their gratitude to the Faculty of Agronomic Sciences of Unesp, Botucatu campus, and all its servers, who contributed to the development of this study.

To the Coordination for the Improvement of Higher Education Personnel (CAPES) - Financing Code 001, for the study grant to the first author.

To the company Sakata Seeds Sudamerica, for donating the seeds used in the experiments.

To the Brazilian people, the funders of a public, quality and free-of-charge education.

\section{Compliance with Ethical Standards}

Author contributions: Conceptualization: FPT, JDR, EOO; Funding acquisition: JDR, EOO; Project administration: EOO; Resources: EOO; Supervision: EOO; Validation: EOO; Visualization: FPT, EOO; Writing - original draft: FPT, EOO; Data curation: FPT, AKLF, RCM, TMCS; Formal analysis: FPT, TMCS; Investigation: FPT, AKLF, RCM; Validation: FPT; Writing - review \& editing: FPT, AKLF, RCM, TMCS, JDR, EOO.

Conflict of Interest: All authors declare that there are no personal or professional conflicts of interest.

Funding: Coordenação de Aperfeiçoamento de Pessoal de Nível Superior (CAPES): granting a doctoral scholarship to the first author.

\section{Literature Cited}

Altintas, S. Effects of prohexadione-calcium with three rates of growth of tomato. African Journal of Biotechnology, v.10, n.75, p.17142-17151, 2011. https://doi.org/10.5897/AJB11.2594.

Alvarenga, M.A.R. Tomate: produção em campo, casa de vegetação e hidroponia. 2 ed. rev. e ampl. Lavras: UFLA, 2013. 455 p.

Baker, N.R.; Rosenqvist, E. Applications of chlorophyll fluorescence can improve crop production strategies: an examination of future possibilities. Journal of Experimental Botany, v.55, n. 403, p.16071621, 2004. https://doi.org/10.1093/jxb/erh196.

Bolhar-Nordenkampf, H.R.; Lon Altintas, S. Effects of prohexadione-calcium with three rates of growth of tomato. African Journal of Biotechnology, v.10, n.75, p.17142-17151, 2011. https://doi.org/10.5897/AJB11.2594.

Alvarenga, M.A.R. Tomate: produção em campo, casa de vegetação e hidroponia. 2.ed. Lavras: UFLA, 2013. 455 p. 
Baker, N.R.; Rosenqvist, E. Applications of chlorophyll fluorescence can improve crop production strategies: an examination of future possibilities. Journal of Experimental Botany, v.55, n. 403, p.16071621, 2004. https://doi.org/10.1093/jxb/erh196.

Bolhar-Nordenkampf, H.R.; Long, S.P.; Baker, N.R.; Oquist, G.; Schreiber, U.L.E.G.; Lechner, E.G. Chlorophyll fluorescence as probe of the photosynthetic competence of leaves in the field: a review of current instrument. Functional Ecology, v.3, n. 4, p.497514, 1989. https://doi.org/10.2307/2389624.

Dragišić Maksimović, J.J.; Poledica, M.M.; Radivojević, D.D.; Milivojević, J.M. Enzymatic profile of' Willamette' raspberry leaf and fruit affected by Prohexadione-Ca and young canes removal treatments. Journal of Agricultural and Food Chemistry, v.65, n.24, p. 5034-5040, 2017. https://doi.org/10.1021/acs. jafc.7b00638.

Espindula, M.C.; Rocha, V.S.; Souza, L.T.D.; Souza, M.A.D.; Grossi, J.A.S. Efeitos de reguladores de crescimento na elongação do colmo de trigo. Acta Scientiarum. Agronomy, v.32, n. 1, p. 109116, 2010. https://doi.org/10.4025/actasciagron.v32i1.943.

Evans, J. R.; Evans, R. R.; Reguscl, C. L.; Rademacher, W. Mode of action, metabolism, and uptake of BAS 125W, Prohexadionecalcium. Hortscience, v. 34, n. 7, p.1200-1201, 1999. https://doi. org/10.21273/HORTSCI.34.7.1200.

Fagan, E.B.; Ono, E.O.; Rodrigues, J.D.; Chalfun Júnior, A.; Dourado Neto, D. Fisiologia vegetal: reguladores vegetais. 1.ed. São Paulo: Andrei, 2015. 302p.

Foyer, C.H.; Fletcher, J.M. Plant antioxidants: colour me healthy. Biologist (London), v.48, n. 3, p. 115-120, 2001. https:// europepmc.org/article/med/11399842. 13.Mar. 2020.

Giannakoula, A.; Ilias, I. Chlorophyll fluorescence and photosystem II activity of tomato leaves as affected by irradiance and prohexadione-calcium. In: Wseas International Conference on Renewable Energy Source, 2007, Arcachon. Proceedings... Arcachon: World Scientific and Engineering Academy and Society, 2007. p. 49-56. https://www.researchgate.net/profile/ Anastasia_Giannakoula/publication/255599563. 25 Feb. 2020.

Giannopolitis, C.N.; Reis, S.K. Superoxide dismutase I. Occurrence in higher plants. Plant Physiology, v.59, n. 2, p.309-314, 1997. https://doi.org/10.1104/pp.59.2.309.

Gill, S.S.; Tuteja, N. Reactive oxygen species and antioxidant machinery in abiotic stress tolerance in crop plants. Plant Physiology and Biochemistry, v.48, n.12, p.909-930, 2010. https://doi.org/10.1016/j.plaphy.2010.08.016.

Guak, S. Effects of prohexadione-Ca, ethephon, and water stress on growth and productivity of 'Golden Delicious'/M.9 apple. Korean Journal of Horticultural Science and Technology, v.31, n. 1, p.38-49, 2013. https://doi.org/10.7235/hort.2013.12191.

Heath, R.L.; Packer, L. Photoperoxidation in isolated chloroplasts. Kinetics and stoichiometry of fatty acid peroxidation. Archives of Biochemistry and Biophysics, v.125, n.1, p.189-198, 1968. https://doi.org/10.1016/0003-9861(68)90654-1.

Instituto Brasileiro de Geografia e Estatística - IBGE. Culturas temporárias e permanentes 2017. https://www.ibge.gov.br/ estatisticasnovoportal/economicas/agricultura-e-pecuaria/9117producao-agricola-municipal-culturastemporarias-e permanentes. html?=\&t=o-que-e. 09 Jun. 2019.
Kim, H.M.; Lee, H.R.; Kang, J.H.; Hwang, S.J. Prohexadione-Calcium Application during Vegetative Growth Affects Growth of Mother Plants, Runners, and Runner Plants of Maehyang Strawberry. Agronomy, v. 9, n. 3, p.155-167, 2019. https://doi.org/10.3390/ agronomy9030155.

Kofidis, G.; Giannakoula, A.; Ilias, I.F. Growth, anatomy and chlorophyll fluorescence of coriander plants (Coriandrum sativum L.) treated with prohexadione-calcium and daminozide. Acta Biologica Cracoviensia, v.50, n. 2, p.55-62. 2008. https://abcbot.pl/ pdf/50_2/055-062-Kofidis.pdf. 15 Feb. 2020.

Krause, G.H.; Weis, E. Chlorophyll fluorescence and photosynthesis: the basics. Annual Review Plant Physiology. Plant Molecular Biology, v.42, n. 1, p.313-349, 1991. https://doi.org/10.1146/ annurev.pp.42.060191.001525.

Maggioni, M.S.; Rosa, C.B.C.J.; Rosa Junior, E.J.; Silva, E.F.; Rosa, Y.B.C.J.; Scalon, S.P.Q.; Vasconcelos, A.A. Desenvolvimento de mudas de manjericão (Ocimum basilicum L.) em função do recipiente e do tipo e densidade de substratos. Revista Brasileira de Plantas Medicinais, v. 16, n. 1, p. 10-17, 2014. https://doi. org/10.1590/S1516-05722014000100002.

Medjdoub, R.; Val, J.; Blanco, A. Physiological effects of prohexadionecalcium in apple trees: effects on parameters related to photoproductivity. The Journal of Horticultural Science and Biotechnology, v. 82, n. 1, p. 126-132, 2007. https://doi.org/10.1 080/14620316.2007.11512209.

Melo, A.P.C. de.; Seleguini, A.; Veloso, V.D.R.S. Peliculização de sementes de tomate associada ao paclobutrazol. Bragantia, v.73, n.2, p. 123-129, 2014. http://dx.doi.org/10.1590/brag.2014.026.

Mouco, M.A.D.C.; Ono, E.O.; Rodrigues, J.D. Inibidores de síntese de giberelinas e crescimento de mudas de mangueira 'Tommy Atkins. Ciência Rural, v.40, n.2, p.273-279, 2010. https://doi. org/10.1590/S0103-84782010000200004.

Ozbay, N.; Ergun, N. Prohexadione calcium on the growth and quality of eggplant seedlings. Pesquisa Agropecuária Brasileira, Brasília, v. 50, n. 10, p.932-938, 2015. https://doi.org/10.1590/S0100204X2015001000009.

Pan, M.; Yin, Y.; Shen, F.; Luo, B.; Tang, X.; He, H.; Chen, D. Effects of prohexadione calcium on physiological index of tobacco seedlings during cold stress. Southwest China Journal of Agricultural Sciences, v.29, n.2, p. 288-293, 2016. https://www.cabdirect.org/ cabdirect/abstract/20173074249. 25 Feb. 2020.

Peixoto, J.V.M.; Moraes, E. R. de; Peixoto, J. L. M.; Nascimento, A. dos Reis, Neves, J.G. Tomaticultura: aspectos morfológicos e propriedades físico-químicas do fruto. Revista Científica Rural, v. 19, n.1, p. 124-131, 2017. http://revista.urcamp.tche.br/index. php/RCR/article/view/96/130. 17 Mar. 2020.

Peixoto, P.H.P.; Cambraia, J.; Sant'Anna, R.; Mosquim, P.R.; Moreira, M.A. Aluminium effects on lipid peroxidation and the activities of enzymes of oxidative metabolism in sorghum. Revista Brasileira de Fisiologia Vegetal, v.11 n.3, p. 137-143, 1999. https://www.researchgate.net/profile/Paulo_Peixoto4/ publication/267338431. 11 Mar. 2020.

Pereira, I. dos S.; Gonçalves, M. A.; Picolotto, L.; Vignolo, G. K.; Antunes, L. E. C. Controle do crescimento de mudas de morangueiro 'Camarosa'cultivadas em substrato comercial pela aplicação de proexadione cálcio. Amazonian Journal of Agricultural and Environmental Sciences, v.59, n.1, p. 93-98, 2016. http://dx.doi. org/10.4322/rca.2126. 
Privé, J.P.; Cline, J.; Fava, E. Influence of prohexadione calcium $\left(\right.$ Apogee $^{\circledR}$ ) on shoot growth of non-bearing mature apple trees in two different growing regions. Canadian Journal of Plant Science, v. 86, n. 1, p. 227-233, 2006. https://doi.org/10.4141/P05-031.

Rachmilevitch, S. Physiological and biochemical indicator for stress tolerance. In: Hang, B. (Ed.). Plant-environment interactions. 3.ed. New York: CRC, 2006. Chap. 11, p.321-356, 2006. https:// doi.org/10.1201/9781420019346.ch11.

Rademacher, W. Growth retardants: effects on gibberellin biosynthesis and other metabolic pathways. Annual Review of Plant Physiology and Plant Molecular Biology, v.51, p.501-531, 2000. https://doi.org/10.1146/annurev.arplant.51.1.501.

Rezapour Fard, J.; Kafi, M.; Naderi, R. The enhancement of drought stress tolerance of Kentucky Bluegrass by prohexadione-calcium treatment. Journal of Ornamental Plants, v. 5, n. 4, p.197-204, 2015. http://jornamental.iaurasht.ac.ir/article_517021.html. 17 Mar. 2020.

Seleguini, A.; Faria Júnior, M.J.de A.; Benett, K.S.S.; Lemos, O.L.; Seno, S. Estratégias para produção de mudas de tomateiro utilizando paclobutrazol. Semina: Ciências Agrárias, v.34, n.2, p. 539-548, 2013. https://doi.org/10.5433/1679-0359.2013v34n2p539.

Taiz, L.;Zeiger, E.; Møller, I. M.; Murphy, A. Fisiologia e desenvolvimento vegetal. 6.ed. Porto Alegre, Artmed. 2017. 858p.

Teisseire, H.; Guy, V. Copper-induced changes in antioxidant enzymes activities in fronds of duckweed (Lemna minor). Plant Science, v. 153, n.1, p. $65-72,2000$. https://doi.org/10.1016/S01689452(99)00257-5.

Thomidis, T.; Zioziou, E.; Koundouras, S.; Navrozidis, I.; Nikolaou, N. Effect of prohexadione-Ca on leaf chlorophyll content, gas exchange, berry size and composition, wine quality and disease susceptibility in Vitis vinifera L. cv Xinomavro. Scientia Horticulturae, v. 238, p.369-374, 2018. https://doi.org/10.1016/j. scienta.2018.05.008.g, S.P.; Baker, N.R.; Oquist, G.; Schreiber, U.L.E.G.; Lechner, E.G. Chlorophyll fluorescence as probe of the photosynthetic competence of leaves in the field: a review of current instrument. Functional Ecology, v.3, n. 4, p.497-514, 1989. https://doi.org/10.2307/2389624.

Dragišić Maksimović, J.J.; Poledica, M.M.; Radivojević, D.D.; Milivojević, J.M. Enzymatic profile of' Willamette' raspberry leaf and fruit affected by Prohexadione-Ca and young canes removal treatments. Journal of agricultural and food chemistry, v.65, n.24, p. 5034-5040, 2017. https://doi.org/10.1021/acs.jafc.7b00638.

Espindula, M.C.; Rocha, V.S.; Souza, L.T.D.; Souza, M.A.D.; Grossi, J.A.S. Efeitos de reguladores de crescimento na elongação do colmo de trigo. Acta Scientiarum. Agronomy, v.32, n. 1, p. 09-116, 2010. https://doi.org/10.4025/actasciagron.v32i1.94310.4025/ actasciagron.v32i1.943.

Evans, J. R.; Evans, R. R.; Reguscl, C. L.; Rademacher, W. Mode of Action, Metabolism, and Uptake of BAS 125W, Prohexadionecalcium. Hortscience, v. 34, n. 7, p.1200-1201, 1999.https://pdfs. semanticscholar.org/35e3/4b11106f79c9776d09299c0b501fb4a 88cc3.pdf. 15 Mai. 2020.

Fagan, E.B.; Ono, E.O.; Rodrigues, J.D.; Chalfun Júnior, A.; Dourado Neto, D. Fisiologia vegetal: Reguladores Vegetais. Primeira edição. São Paulo: Andrei, 2015, p. 302.
Foyer, C.H.; Fletcher, J.M. Plant antioxidants: colour me healthy. Biologist (London, England), v.48, n. 3, p. 115-120, 2001. https:// europepmc.org/article/med/11399842. 13.Mar. 2020.

Giannakoula, A.; Ilias, I. Chlorophyll fluorescence and photosystem II activity of tomato leaves as affected by irradiance and prohexadione-calcium. In: Wseas International Conference on Renewable Energy Source. Arcachon: World Scientific and Engineering Academy and Society, 2007, p. 49-56. https:// www.researchgate.net/profile/Anastasia_Giannakoula/ publication/255599563_Chlorophyll_Fluorescence_ and_Photosystem_II_Activity_of_Tomato_Leaves_as_ Affected_by_Irradiance_and_ProhexadioneCalcium/ links/5432be770cf22395f29c3e72/Chlorophyll-Fluorescenceand-Photosystem-II-Activity-of-Tomato-Leaves-as-Affected-by Irradiance-and-Prohexadione-Calcium.pdf. 25 Fev. 2020.

Giannopolitis, C.N.; Reis, S.K. Superoxide dismutase I. Occurrence in higher plants. Plant Physiology, v.59, n. 2, p.309-314, 1997. https://doi.org/10.1104/pp.59.2.309.

Gill, S.S.; Tuteja, N. Reactive oxygen species and antioxidant machinery in abiotic stress tolerance in crop plants. Plant Physiology and biochemistry, v.48, n.12, p.909-930, 2010. https://doi.org/10.1016/j.plaphy.2010.08.016.

Guak, S. Effects of prohexadione-Ca, ethephon, and water stress on growth and productivity of 'Golden Delicious'/M.9 apple. Korean Journal of Horticultural Science and Technology, v.31, $n$. 1, p.38-49, 2013. https://doi.org/10.7235/hort.2013.12191.

Heath, R.L.; Packer, L. Photoperoxidation in isolated chloroplasts. Kinetics and stoichiometry of fatty acid peroxidation. Archives of Biochemistry and Biophysics, v.125, n.1, p.189-198, 1968. https://doi.org/10.1016/0003-9861(68)90654-1.

IBGE - Instituto Brasileiro de Geografia e estatística. Culturas temporárias e permanentes 2017. 2018. https:// www.ibge.gov.br/estatisticasnovoportal/economicas/ agricultura-e-pecuaria/9117-producao-agricola-municipalculturastemporarias-e permanentes. html?=\&t=0-que-e . 09 Jun. 2019.

Kim, H.M.; Lee, H.R.; Kang, J.H.; Hwang, S.J. Prohexadione-Calcium Application during Vegetative Growth Affects Growth of Mother Plants, Runners, and Runner Plants of Maehyang Strawberry. Agronomy, v. 9, n. 3, p.155-167, 2019. https://doi.org/10.3390/ agronomy9030155.

Kofidis, G.; Giannakoula, A.; Ilias, I.F. Growth, anatomy and chlorophyll fluorescence of coriander plants (Coriandrum sativum $\mathrm{L}$.) treated with prohexadione-calcium and daminozide. Acta Biologica Cracoviensia, v.50, n. 2, p.55-62. 2008. https:// www.researchgate.net/profile/Anastasia_Giannakoula/ publication/242605214_Growth_anatomy_and_Chlorophyll_ fluorescence_of_coriander_plants_Coriandrum_sativum_L_ treated_with_prohexadionecalcium_and_daminozide/ links/5432be770cf22395f29c3e73.pdf. 15 Fev. 2020.

Krause, G.H.; Weis, E. Chlorophyll fluorescence and photosynthesis: the basics. Annual Review Plant Physiology. Plant Molecular Biology, v.42, n. 1, p.313-349, 1991. https://doi.org/10.1146/ annurev.pp.42.060191.001525. 
Maggioni, M.S.; Rosa, C.B.C.J.; Rosa Junior, E.J.; Silva, E.F.; Rosa, Y.B.C.J.; Scalon, S.P.Q.; Vasconcelos, A.A. Desenvolvimento de mudas de manjericão (Ocimum basilicum L.) em função do recipiente e do tipo e densidade de substratos. Revista Brasileira de Plantas Medicinais, v. 16, n. 1 , p. 10-17, 2014. https://www.locus.ufv.br/bitstream/ handle/123456789/18623/artigo.pdf?sequence=1. 02 Mar. 2020.

Medjdoub, R.; Val, J.; Blanco, A. Physiological effects of prohexadionecalcium in apple trees: effects on parameters related to photoproductivity. The Journal of Horticultural Science and Biotechnology, v. 82, n. 1, p. 126-132, 2007. https://doi.org/10.1080 /14620316.2007.11512209.

Melo, A.P.C. de.; Seleguini, A.; Veloso, V.D.R.S. Peliculização de sementes de tomate associada ao paclobutrazol. Bragantia, v.73, n.2, p. 123129, 2014. http://dx.doi.org/10.1590/brag.2014.026

Mouco, M.A.D.C.; Ono, E.O.; Rodrigues, J.D. Inibidores de síntese de giberelinas e crescimento de mudas de mangueira 'Tommy Atkins. Ciência Rural, v.40, p.273-279, 2010. https://doi.org/10.1590/ S0103-84782010000200004.

Ozbay, N.; Ergun, N. Prohexadione calcium on the growth and quality of eggplant seedlings. Pesquisa Agropecuária Brasileira, Brasília, v. 50, n. 10, p.932-938, 2015. http://dx.doi.org/10.1590/S0100204X2015001000009.

Pan, M.; Yin, Y.; Shen, F.; Luo, B.; Tang, X.; He, H.; Chen, D. Effects of prohexadione calcium on physiological index of tobacco seedlings during cold stress. Southwest China Journal of Agricultural Sciences, v.29, n.2, p. 288-293, 2016. https://www.cabdirect.org/?target=\%2fc abdirect\%2fsearch\%2f\%3fq\%3ddo\%253a\%2522Southwest\%2bChina \%2bJournal\%2bof\%2bAgricultural\%2bSciences\%2522. 25 Fev. 2020.

Peixoto, P.H.P.; Cambraia, J.; Sant'Anna, R.; Mosquim, P.R.; Moreira, M.A. Aluminium effects on lipid peroxidation and the activities of enzymes of oxidative metabolism in sorghum. Revista Brasileira de Fisiologia Vegetal, v.11 n.3, p. 137-143, 1999.https://www.researchgate.net/ profile/Paulo_Peixoto4/publication/267338431_ALUMINUM_ EFFECTS_ON_LIPID_PEROXIDATION_AND_ON_THE_ACTIVITIES_ OF_ENZYMES_OF_OXIDATIVE_METABOLISM_IN_SORGHUM/ links/544db4960cf2d6347f45cb09.pdf. 11 Mar. 2020.

Peixoto, J.V.M.; Moraes, E. R. de; Peixoto, J. L. M.; Nascimento, A. dos Reis, Neves, J.G. Tomaticultura: aspectos morfológicos e propriedades físico-químicas do fruto. Revista Científica Rural, Bagé, v. 19, n.1, p. 124-131, 2017. http://revista.urcamp.tche.br/index.php/RCR/ article/view/96/130. 17 Mar. 2020.
Pereira, I. dos S.; Gonçalves, M. A.; Picolotto, L.; Vignolo, G. K.; Antunes, L. E. C. Controle do crescimento de mudas de morangueiro 'Camarosa'cultivadas em substrato comercial pela aplicação de proexadione cálcio. Amazonian Journal of Agricultural and Environmental Sciences, v.59, n.1, p. 93-98, 2016. http://dx.doi. org/10.4322/rca.2126.

Privé, J.P.; Cline, J.; Fava, E. Influence of prohexadione calcium $\left(\right.$ Apoge $^{\circledR}$ ) on shoot growth of non-bearing mature apple trees in two different growing regions. Canadian Journal of Plant Science, Ottawa, v. 86, n. 1, p. 227-233, 2006. https://doi.org/10.4141/ P05-031.

Rachmilevitch, S. Physiological and biochemical indicator for stress tolerance. Plant-environment interactions, p.321-356, 2006. https://ci.nii.ac.jp/naid/10029300702/. 10 Jan. 2020.

Rademacher, W. Growth retardants: effects on gibberellin biosynthesis and other metabolic pathways. Annual Review of Plant Physiology and Plant Molecular Biology, v.51, p.501-531, 2000. https://doi.org/10.1146/annurev.arplant.51.1.501.

Rezapour Fard, J.; Kafi, M.; Naderi, R. The Enhancement of Drought Stress Tolerance of Kentucky Bluegrass by Prohexadione-Calcium Treatment. Journal of Ornamental Plants, v. 5, n. 4, p.197-204, 2015. http://jornamental.iaurasht.ac.ir/article_517021_7493e9 23927bc323dea206e1b5ae7006.pdf. 17 Mar. 2020.

Seleguini, A.; Faria Júnior, M.J.de A.; Benett, K.S.S.; Lemos, O.L.; Seno, S. Estratégias para produção de mudas de tomateiro utilizando paclobutrazol. Semina: Ciências Agrárias, v.34, p. 539-548, 2013. https://doi.org/10.5433/1679-0359.2013v34n2p539.

Taiz, L.;Zeiger, E.; Møller, I. M.; Murphy, A. Fisiologia e desenvolvimento vegetal. 6a ed. Porto Alegre, Artmed. 2017. 858p.

Teisseire, H.; Guy, V. Copper-induced changes in antioxidant enzymes activities in fronds of duckweed (Lemna minor). Plant Science, v. 153, p. 65-72, 2000. https://doi.org/10.1016/S01689452(99)00257-5.

Thomidis, T.; Zioziou, E.; Koundouras, S.; Navrozidis, I.; Nikolaou, N. Effect of prohexadione-Ca on leaf chlorophyll content, gas exchange, berry size and composition, wine quality and disease susceptibility in Vitis vinifera L. cv Xinomavro. Scientia Horticulturae, v. 238, p.369-374, 2018. https://doi.org/10.1016/j. scienta.2018.05.008. 